\title{
Author Correction: Structural basis of neuropeptide Y signaling through Y1 receptor
}

Chaehee Park (D), Jinuk Kim, Seung-Bum Ko, Yeol Kyo Choi (D), Hyeongseop Jeong (D), Hyeonuk Woo,

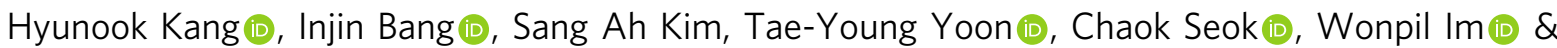
Hee-Jung Choi (i)

Correction to: Nature Communications https://doi.org/10.1038/s41467-022-28510-6, published online 14 February 2022.

In this article, the affiliation Institute for Molecular Biology and Genetics, Seoul National University, Seoul 08826, Republic of Korea for Tae-Young Yoon was missing. The original article has been corrected.

Published online: 25 February 2022

\begin{abstract}
(c) (i) Open Access This article is licensed under a Creative Commons Attribution 4.0 International License, which permits use, sharing, adaptation, distribution and reproduction in any medium or format, as long as you give appropriate credit to the original author(s) and the source, provide a link to the Creative Commons license, and indicate if changes were made. The images or other third party material in this article are included in the article's Creative Commons license, unless indicated otherwise in a credit line to the material. If material is not included in the article's Creative Commons license and your intended use is not permitted by statutory regulation or exceeds the permitted use, you will need to obtain permission directly from the copyright holder. To view a copy of this license, visit http://creativecommons.org/licenses/by/4.0/.
\end{abstract}

(C) The Author(s) 2022 